\title{
Prevalence of Toxoplasma gondii antibodies in wild boar (Sus scrofa) from Strzałowo Forest Division, Warmia and Mazury Region, Poland
}

\author{
Martyna Puchalska ${ }^{1, A-B, D \oplus}$, Anna Maria Pyziel ${ }^{1, B}{ }^{\oplus}$, Jan Wiśniewski1,B๑ , \\ Żaneta Steiner-Bogdaszewska ${ }^{2, B}{ }^{\oplus}$, Daniel Klich ${ }^{3, C} \odot$, Krzysztof Anusz',E-F® \\ ${ }^{1}$ Department of Food Hygiene and Public Health Protection, Institute of Veterinary Medicine, Warsaw University of Life \\ Sciences (SGGW), Poland \\ ${ }^{2}$ W. Stefański Institute of Parasitology, Polish Academy of Sciences, Warsaw, Poland \\ ${ }^{3}$ Department of Animal Genetics and Conservation, Institute of Animal Science, Warsaw University of Life Sciences \\ (SGGW), Poland \\ A - Research concept and design, B - Collection and/or assembly of data, C - Data analysis and interpretation, \\ $D$ - Writing the article, E-Critical revision of the article, F-Final approval of article \\ Puchalska M, Pyziel AM, Wiśniewski J, Steiner-Bogdaszewska Ż, Klich D, Anusz K. Prevalence of Toxoplasma gondii antibodies in wild \\ boar (Sus scrofa) from Strzałowo Forest Division, Warmia and Mazury Region, Poland. Ann Agric Environ Med. 2021 ; $28(2)$ : $237-242$.
} doi: $10.26444 / a a e m / 118883$

\begin{abstract}
Introduction and objective. Toxoplasmosis is an important zoonosis caused by a protozoan, Toxoplasma gondii. Raw or undercooked venison may be a source of infection in humans. The aim of the study was to determine the prevalence of T. gondii antibodies in wild boar from the Strzałowo Forest Division of the Warmia and Mazury Region of Poland.

Materials and method. A total of 90 samples were collected from 50 wild boar: 40 from both tongue and diaphragm muscles, 4 from diaphragm muscles and six from tongue muscles. Samples were analyzed using the commercial PrioCHECK ${ }^{\circledR}$ Toxoplasma Ab porcine ELISA, according to the manufacturer's instructions.

Results. T. gondii antibodies were detected in 24 of 50 (48\%) tested animals. T. gondii antibodies were detected in 40 of $90(44.4 \%)$ tested samples (21 of tongue muscles and 19 of diaphragm muscles). In the 40 wild boar that provided samples of meat juice from the tongue and diaphragm muscles, specific antibodies were more prevalent in the tongue (20 of 40 animals $-50 \%$ ) than in the diaphragm muscles (17 of 40 animals $-42.5 \%$ ).

Conclusions. The study revealed a high percentage of wild boar seropositive to T. gondii. Muscle samples to obtain meat juice are easily available and simple to collect, even on the hunting grounds, which makes them suitable material for detecting T. gondii antibodies in wild boar. Wild boar are essential to T. gondii circulation in the environment, and raw or undercooked venison may be a source of human infections with this parasite.
\end{abstract}

\section{Key words}

Poland, seroprevalence, antibodies, toxoplasmosis, Toxoplasma gondii, wild boar

\section{INTRODUCTION}

Toxoplasmosis is one of the most important zoonoses caused by the protozoan Toxoplasma gondii $[1,2]$, a parasite of significant importance in medicine and veterinary medicine, widespread worldwide [3] and capable of infecting most species of warm-blooded animals, including humans [4]. The European Food Safety Authority (EFSA) has recognized toxoplasmosis as a parasitic zoonosis with the highest prevalence in humans [5]. It is also classified by the FAOWHO as belonging to the "top ten" of food-borne parasites [6, 7]. T. gondii infections are common in many species of farm and non-domesticated animals sourced for food. For this reason, the EFSA recommends the monitoring of the presence of the parasite in sheep, goats, pigs and wild game [5].

Species belonging to the Felidae family are definitive hosts in the complex life cycle of T. gondii [8]. The faeces they excrete into the environment contain millions of oocysts [9] capable of infecting a wide range of hosts through the contamination

Address for correspondence: Martyna Puchalska, Department of Food Hygiene and Public Health Protection, Institute of Veterinary Medicine, Warsaw University of Life Sciences - SGGW, Poland

E-mail: martyna_puchalska@sggw.pl

Received: 18.11.2019; accepted: 10.03.2020; first published: 06.04.2020 of soil, water and food [10,11]. Most warm-blooded animals can serve as intermediate hosts [12], although T. gondii can also circulate in the environment without the participation of definitive hosts (via tissue cysts in tissues of intermediate hosts), as well as without participation of intermediate hosts (via oocysts contaminated the environment) [12]. Humans can be infected via three routes: by ingestion of sporulated oocysts that pollute the environment, by consuming raw or undercooked meat containing parasite tissue cysts, and as a result of an intrauterine infection [2]. The infection is usually asymptomatic or produces only mild symptoms. Severe complications can occur in certain groups: encephalitis, brain abscesses and death in immunocompromised individuals [13, 14], pre-eclampsia, psychiatric disorders, abortion and foetal abnormality in pregnant women $[15,16,17]$, and behavioural changes, neuropsychiatric disorders, and infertility in healthy humans and animals [18, 19, 20, 21, 22].

Wild boar (Sus scrofa) are common throughout Europe and are the most popular game species, with the exception of the British Isles, Denmark, and a significant part of the Scandinavian Peninsula $[4,23]$. Its natural habitat are forests of various tree species composition that ensure an abundance of food and cover [23], and prefers swampy areas with access to water [24]. In recent decades, the size 
of wild boar populations has increased in most European countries $[9,25]$, and according to the Statistics Poland data, their number in Poland in 2017 reached 215,700 individuals (as of 10 March 2017) [26]. Wild boar is an omnivorous species in which diet plants account for about $90 \%$, and animals, including a significant number of species from the Muridae family - about $10 \%$. Wild boar also search for food at landfills, city parks or suburban areas [23]. The species shows high adaptability to changing climatic and environmental conditions [6] and high reproductive potential [27]. Wild boar serve as reservoirs of numerous viruses, bacteria and parasites [25], which can be a potential source of human, farm and companion animals diseases [27, 28, 29]. The increase in their population size observed in recent years increases the risk of wild boar contact with people and pigs, and thus the risk of pathogen transmission, including zoonotic pathogens such as T. gondii [30]. The consumption of raw or undercooked meat is considered an important route of infection for humans $[1,31,32,33,34]$. However, the source of infection is difficult to determine [35], and varies depending on the populations tested (e.g. eating, hygienic and cultural habits) [36]. T. gondii tissue cysts may be present in the meat of wild boar and other game species, and for this reason, venison may be a source of human infections with this parasite [37]. For T. gondii seropositivity has been shown to correlate with chronic infection in pigs. In chronic infection, cysts remains in the tissues of the host [38], which is why meat and offal from seropositive individuals should be considered potentially infectious.

Wild boar are the intermediate host of T. gondii, although it is unclear whether infection occurs primarily by ingestion of tissue cysts from the meat of prey, through scavenging, or by ingestion of oocysts from the environment [6]. Carcass residues left on the hunting grounds may also be a source of infection. As an omnivorous species, wild boar is considered a bioindicator of environmental pollution with $T$. gondii $[35,37]$. T. gondii infection in wild boar is of limited clinical importance [39]; it is typically asymptomatic and chronic, where animals show specific antibodies and have tissue cysts [6], but clinical congenital toxoplasmosis has also been reported [40]. The occurrence of T. gondii infections in wild boar is important from the perspective of public health protection, as increased consumption of venison, including meat obtained from wild boars, is considered a risk factor for T. gondii infection in humans [32].

As wild boar seem to be an effective bioindicator of T. gondii circulation in the environment [4], and venison consumption gains in popularity, the study aimed to determine the prevalence of T. gondii antibodies in wild boar in the Strzałowo Forest Division.

\section{MATERIALS AND METHOD}

The study material was obtained from 50 wild boar, aged about one-year or older, shot during hunting parties held within the Strzałowo Forest Division (Warmia and Mazury Region, Mrągowo County) between November 2017 - January 2018. The samples included $50 \mathrm{~g}$ of diaphragm muscles and $50 \mathrm{~g}$ of tongue muscles, packed into separate string bags, labelled and transported to a laboratory, where they were stored at $-20^{\circ} \mathrm{C}$. Diaphragm muscle samples were collected from 44 boars and tongue muscles from 46 animals.
Study area. Strzałowo Forest Division is located within the Warmia and Mazury Region of Mrągowo County $\left(53^{\circ} 77^{\prime} \mathrm{N}\right.$, $\left.21^{\circ} 46^{\prime} \mathrm{E}\right)$. The area features highly variable topography, interspersed with a large number of lakes (e.g. Mokre, Majcz Wielki and Kołowin), swamps and peatlands. It is covered with brunic arenosols, luvisols and peat-derived soils. Deciduous tree species dominant, such as hornbeam, oak, elm and ash. The Game Breeding Centre of the Strzałowo Forest Division offers hunters the possibility to hunt wild boar, deer, roe deer and small game. In the vicinity, in Kosewo Górne, there is also a Research Station of the Institute of Parasitology of the Polish Academy of Sciences that breeds deer, fallow deer and mouflons.

Meat juice sampling. Tongue and diaphragm muscle samples were frozen, then thawed and squeezed. Meat juice samples thus obtained were collected with an automatic pipette, placed in $1.5 \mathrm{ml}$ Eppendorf tubes and stored at $-20^{\circ} \mathrm{C}$ until analysis. A total of 90 samples were harvested from 50 wild boar: 40 of both tongue and diaphragm muscles, four of diaphragm muscles alone, and six from tongue muscles alone.

Detection of Toxoplasma gondii antibodies. Meat juice samples were tested using a commercial ELISA kit (EnzymeLinked Immunosorbent Assay; PrioCHECK ${ }^{\oplus}$ Toxoplasma Ab porcine; Prionics, Switzerland), with sensitivity and specificity in pigs of $98 \%$ and $99.6 \%$, respectively [41]. The assay was assembled strictly according to the manufacturer's instructions. Briefly, Washing Fluid working solution was prepared by diluting $30 \mathrm{ml}$ of the initial solution $(10 \mathrm{x})$ with $270 \mathrm{ml}$ of demineralized water. Then, with the use of Sample Diluent and a titration plate, two dilution series (1:10) of control sera (positive, weakly positive and negative control) and diluted meat juice samples were prepared. Control wells comprised $80 \mu \mathrm{l}$ of Sample Diluent and $20 \mu \mathrm{l}$ of the control sera diluted 1:10. The other wells contained $100 \mu \mathrm{l}$ of diluted meat juice. The plate was incubated for $60 \pm 1 \mathrm{~min}$ at room temperature $\left(22 \pm 3^{\circ} \mathrm{C}\right)$ and rinsed four times with Wash Fluid working solution. At the next step, another working solution (1:30) of Conjugate in Conjugate Diluent was prepared. Each well was supplemented with $100 \mu \mathrm{l}$ of Conjugate working solution. The plate was incubated for $60 \pm 1 \mathrm{~min}$ at room temperature, and rinsed four times with Wash Fluid working solution. $100 \mu$ l of the substrate was then added to each well, and the plate incubated for $15 \pm 1 \mathrm{~min}$ at room temperature. The reaction was stopped by adding $100 \mu \mathrm{l}$ of Stop Solution into each well. The results were read with an ELISA plate reader (Epoch, BioTek, USA) at $450 \mathrm{~nm}$ (reference filter $620 \mathrm{~nm}$ ).

The result for each sample was calculated using the formula: PP (Percentage of Positivity $)=\left[\left(\mathrm{OD}_{450 \mathrm{~nm}}\right.\right.$ Sample $\left.\left.\mathrm{OD}_{450 \mathrm{~nm}} \mathrm{NC}\right) /\left(\mathrm{OD}_{450 \mathrm{~nm}} \mathrm{PC}-\mathrm{OD}_{450 \mathrm{~nm}} \mathrm{NC}\right)\right]^{\star} 100$, where $\mathrm{NC}$ was the negative control and PC the positive control. The result was considered reliable if the control sera met the following criteria: mean $\mathrm{OD}_{450} \mathrm{PC}>1.2$; mean $\mathrm{PP}$ of weakly positive control $>35 \%$; mean $\mathrm{OD}_{450} \mathrm{NC}<0.150$. Results with $\mathrm{PP} \geq$ $20 \%$ were deemed positive.

Statistical analysis. Logistic regression analysis in a generalized linear model was used to compare the prevalence of Toxoplasma gondii antibodies in meat juice samples obtained from diaphragm and tongue muscles. The analysis only included cases when the presence of antibodies was determined in both tongue and diaphragm meat juice 
samples from the same animal. Binomial distribution and logit link function were employed. The dependent variable was the presence or absence of T. gondii antibodies and the factor was tissues type (diaphragm or tongue). Statistical analysis was performed with SPSS Software (version 24.0, IBM Corporation, Armonk, NY).

\section{RESULTS}

The study involved a total of 90 samples collected from 50 wild boar. Toxoplasma gondii antibodies were detected in 24 of 50 (48\%) tested animals, and in 40 of 90 (44.4\%) tested samples (21 of tongue muscles and 19 of diaphragm muscles). In the 40 wild boar that provided samples of meat juice from the tongue and diaphragm muscles, specific antibodies were more prevalent in the tongue (20 of 40 animals - 50\%) than in the diaphragm muscles (17 of 40 animals $-42.5 \%$ ). In five animals that provided meat juice from both tongue and diaphragm muscles, the antibodies were detected in only one type of muscle (tongue in four boar and diaphragm in one). Statistical analysis revealed no significant differences in the prevalence of T. gondii antibodies in the meat juice from tongue and diaphragm muscles $\left(\chi^{2}=0.453, \mathrm{df}=1 ; \mathrm{p}=0.501\right)$. Both types of samples showed a similar prevalence of T. gondii antibodies.

\section{DISCUSSION}

Many studies have been carried out in recent years on the prevalence of Toxoplasma gondii antibodies in free-range and bred boar in many regions of the world, including Japan [42], the United States [27, 28, 30, 43], Argentina [6], Brazil [44], China [45, 46], and Korea [35, 47]. Numerous studies have also been conducted in Europe. The presented study confirmed a high prevalence of T. gondii antibodies in the investigated animals $(48 \%, \mathrm{n}=50)$, which makes Poland one of the countries with the highest percentage of $T$. gondii seropositive wild boar. Similar results were obtained in Spain (38.4\%, MAT) [48], Italy (43.3\%, ELISA) [32], Sweden (49.5\%, ELISA) [49], and the Czech Republic (39.6\%, ELISA) [9]. The percentage of seropositive wild boar was lower in several studies conducted in the Czech Republic (15.4\% and 26.2\%) [31, 37], Spain (23.8\%) [50] and Sweden (28.6\%) [29], as well as in France $(16.8 \%$ and $17.6 \%)[4,51]$, Switzerland (6.7\%) [2], The Netherlands (24.4\%) [39], Slovakia (8.1\%) [3], Finland (33\%) [52], Portugal (20.6\%) [1], Denmark (27.7\%) [53], Greece (5.2\%) [25], Romania (16\%) [54], Italy (14\%) [55], Latvia (33.2\%) [56] and Estonia (24\%) [38].

The current study indicated a higher percentage of seropositive wild boars than most earlier works from Poland. Sroka et al. [57] reported the presence of specific antibodies in $21.1 \%$ (DAT), while Witkowski et al. [58] in 37.6\% (ELISA) of tested animals. Only Wiszniewska-Łaszczych et al. [34] reported the presence of specific antibodies in $71 \%$ of tested wild boar. Data on the occurrence of antibodies to T. gondii in wild animals are scarce. The research was carried out in omnivores (wild boar), carnivores (raccoons) [59] and herbivores (European bison) [60].

In the current study, a commercial ELISA kit was used for detecting antibodies to T. gondii in serum and meat juice samples obtained from pigs which used an anti-pig IgG conjugate. Wild boar and pigs are close-related species belonging to the family Suidae, subfamily Sus [34], and tests using anti-pig IgG conjugate, intended for use in pigs only or in several animal species (pigs, ruminants, cats and dogs), have been successfully used in the diagnosis of T. gondii infections in wild boars $[31,32,34,35,47,50,53$, 58]. Moreover, commercial ELISA kit intended for use in pigs, ruminants, cats and dogs, was used for comparison of the results obtained for wild boar by an in-house ELISA, and agreement between the two ELISA tests was evaluated as excellent [9]. In pigs and wild boar, specific antibodies remain detectable for a long time after infection, probably for the entire lifetime of the animal. A correlation was also noted between detection of the antibodies and parasite isolation [56], even though some authors believe this claim to be unsubstantiated [2]. Although the results of different studies provide information on the presence of T. gondii antibodies in wild boar, they should not be directly compared due to different methodology, lack of standardized research methods (different sensitivity, specificity and limiting thresholds), different types and number of tested samples, and methods of their collection, origin of the animals, as well as geographical $[55,61]$ and climatic differences, and different degree of soil contamination with the oocysts.

Despite EFSA recommendations on the monitoring of T. gondii infections in sheep, goats, pigs and game animals [5], no such programme has been implemented for any food animals. Infection is usually asymptomatic and there is no way to distinguish infected from uninfected carcasses during slaughter inspection $[5,31,34]$. The tissue cysts of T. gondii are also undetectable during routine examination of meat for trichinosis, based on the magnetic stirrer method for pooled-sample digestion, referred to in Regulation 2015/1375 of 10 August 2015, which provides specific rules on official controls for Trichinella in meat. Therefore, tests for the presence of T. gondii antibodies in hunted wild boar could be useful for public health protection. Sampling wild boar blood can be difficult. In some studies, blood samples for serum were collected by hunters on the hunting grounds from the peritoneal cavities or hearts of animals [25, 35, 37, 55]. This, however, is technically complicated and requires practical training. Muscle samples for obtaining meat juice are easily available and collectable even on the hunting grounds, which makes them a convenient material for the detection of $T$. gondii antibodies in food animals. Moreover,

Table 1. Prevalence of antibodies to Toxoplasma gondii in wild boars from Strzałowo Forest Division, Warmia and Mazury region, Poland

\begin{tabular}{|c|c|c|c|c|c|c|c|c|c|c|c|c|c|c|}
\hline \multirow{2}{*}{$\begin{array}{l}\text { Region } \\
\text { Warmia } \\
\text { and } \\
\text { Mazury }\end{array}$} & \multirow{2}{*}{$\begin{array}{c}\text { Poviat } \\
\text { Mrągowo }\end{array}$} & \multicolumn{2}{|c|}{$\begin{array}{c}\text { Total } \\
\text { (tested animals) }\end{array}$} & \multicolumn{2}{|c|}{$\begin{array}{l}\text { Total (meat } \\
\text { juice samples) }\end{array}$} & \multicolumn{2}{|r|}{ Tongues } & \multicolumn{2}{|c|}{ Diaphragms } & \multicolumn{5}{|c|}{$\begin{array}{l}\text { Among } 40 \text { wild boars that provided samples of meat juice } \\
\text { from tongue and diaphragm muscles }\end{array}$} \\
\hline & & $\mathrm{N}$ & Positive (\%) & $\mathrm{N}$ & Positive (\%) & $\mathrm{N}$ & Positive (\%) & $\mathrm{N}$ & Positive (\%) & $\begin{array}{l}\text { Tongues } \\
\text { positive } \\
\text { samples }\end{array}$ & $\begin{array}{c}\text { Diaphragms } \\
\text { positive } \\
\text { samples }\end{array}$ & $\begin{array}{c}\text { Only } \\
\text { tongue } \\
\text { positive }\end{array}$ & $\begin{array}{c}\text { Only } \\
\text { diaphragm } \\
\text { positive }\end{array}$ & $\begin{array}{c}\text { Both } \\
\text { samples } \\
\text { positive }\end{array}$ \\
\hline & & 50 & 24 (48\%) & 90 & 40 (44.4\%) & 46 & 21 (45.7\%) & 44 & 19 (43.2\%) & $20(50 \%)$ & 17 (42.5\%) & 4 & 1 & 16 \\
\hline
\end{tabular}


diaphragm or tongue muscles can be used interchangeably, as they provide virtually the same results. This is important, as collecting a complete set of samples is not always possible; in some situations, when taking blood samples is impossible, samples for testing may be taken only from carcasses at the venison collection centres.

Wild boar can became infected by ingestion of the oocysts polluting the environment and by consuming an intermediate host of $T$. gondii (e.g. a rodent or bird) with tissues containing infective forms of parasite. In Poland, there is a limited incidence of hosts from the Felidae family (lynxes) in the natural environment [62], therefore the possibility of shedding the oocysts and contamination of the environment by felids in conditions of large forest complexes seems to be of minimal significance. Toxoplasmosis has been diagnosed in some species of wild animals in Poland, such as small rodents, hare, red fox, badger, roe deer and red deer, which play an important role in the transmission of T. gondii in the natural environment [34]. Thus, wild boar, as a scavenger, seems to be more often infected by eating tissues of other intermediate hosts. T. gondii infection in wild boar could also be associated with soil pollution with $T$. gondii oocysts and the environmental conditions extant within the Strzałowo Forest Division.

No data are available on the population of stray cats infected with T. gondii in the studied area. Lopes et al. detected T. gondii antibodies in 26 of 52 (50\%) free-ranging birds [63]. This indicates that T. gondii tissue cysts may be present in their tissues and organs. Moreover, the researchers demonstrated the presence of specific antibodies in 18 of 26 (69.2\%) common buzzards (Buteo buteo), which probably reflected the considerable prevalence of $T$. gondii infection in small animals (e.g. small mammals) which are source of food for the birds of prey [63]. Kijlstra et al. reported a significant decrease in the number of seropositive pigs on three organic farms following implementation of a rodent control programme. The percentage of pigs with detectable specific antibodies decreased from $8-17 \%$ to $0-10 \%$ [64]. This suggests a significant role of rodents in spreading T. gondii infections in animals.

People working with raw meat should be aware of the associated risks and should complete appropriate training. Hunters in particular are often exposed to raw venison. Together with their families they may become infected during evisceration and other stages of venison processing [3]. The meat of hunted wild boar is often consumed directly by the hunters and their families [38, 55], and cases of acute toxoplasmosis have been reported in people who consumed raw meat from infected wild boar $[48,63]$. As people may easily become infected during evisceration and other stages of wild boar carcass processing, appropriate precautions should be taken [63]. The practiced by some hunters of leaving carcass residues on the hunting grounds may further increase the role of wild boars in spreading T. gondii infections [55]. These residues can be consumed by other animals - mostly other wild boar, predators (including cats) or pigs - and serve as sources of infection $[43,48,55,63]$. Therefore, carcass residues should be removed from the hunting grounds, burned or buried, to prevent them from being eaten by carnivores and omnivores.

\section{CONCLUSIONS}

1) The study revealed a high percentage of wild boar seropositive to T. gondii.

2) Muscle samples to obtain meat juice are easily available and simple to collect even on the hunting grounds, which makes them suitable material for detecting T. gondii antibodies in wild boar.

3) Wild boar are essential to T. gondii circulation in the environment, and raw or undercooked venison may be a source of human infections with this parasite.

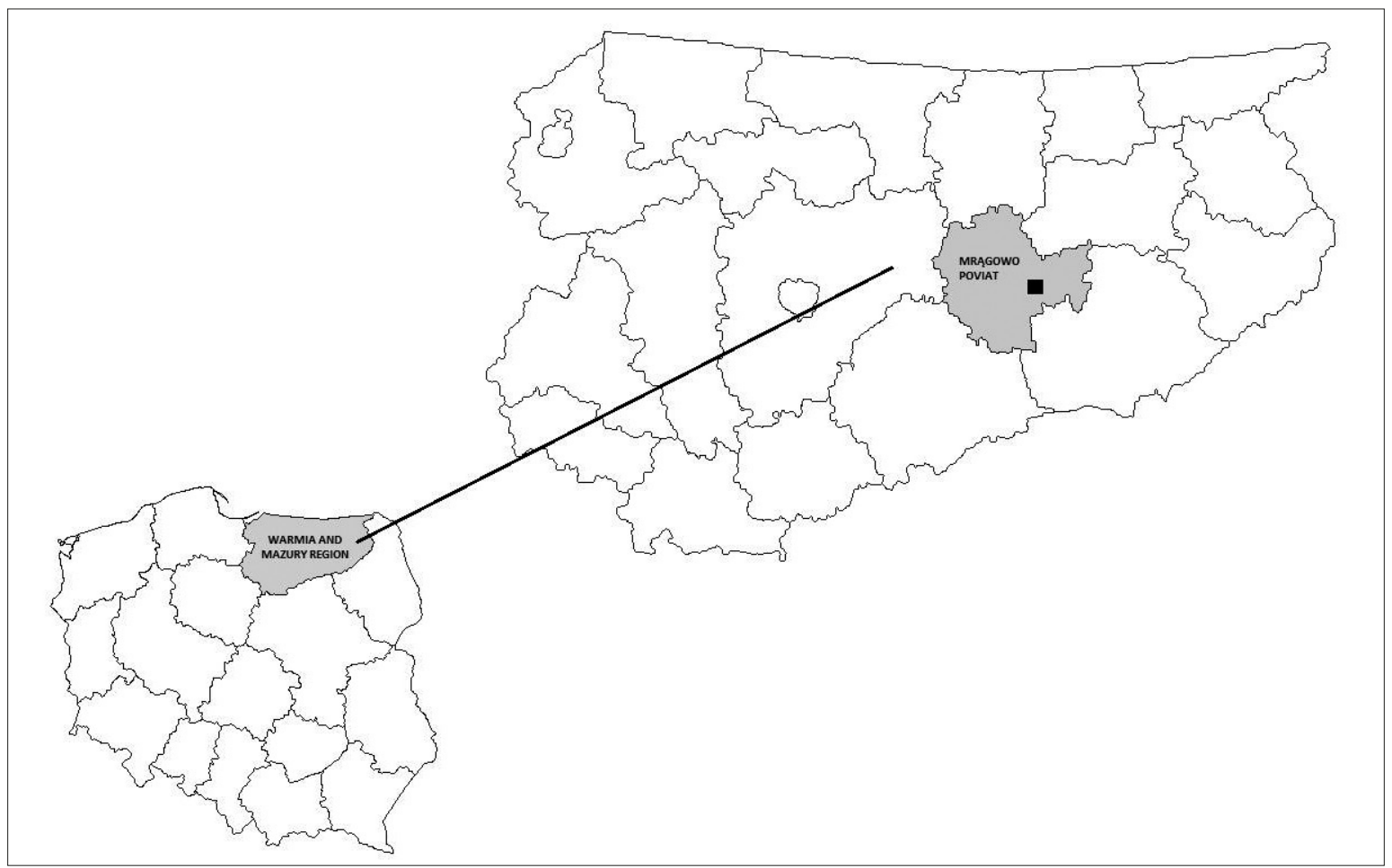

Figure 1. Map of Poland showing the origin of the examined animals 


\section{REFERENCES}

1. Coelho C, Vieira-Pinto M, Faria AS, Vale-Gonçalves H, Veloso O, Paiva-Cardoso Md et al. Serological evidence of Toxoplasma gondii in hunted wild boar from Portugal. Vet Parasitol. 2014; 202(3-4): 310-312. https://doi.org/10.1016/j.vetpar.2014.03.013

2. Berger-Schoch AE, Bernet D, Doherr MG, Gottstein B, Frey CF. Toxoplasma gondii in Switzerland: a serosurvey based on meat juice analysis of slaughtered pigs, wild boar, sheep and cattle. Zoonoses Public Health. 2011; 58(7): 472-478. https://doi.org/10.1111/j.1863 2378.2011.01395.x

3. Antolová D, Reiterová K, Dubinský P. Seroprevalence of Toxoplasma gondii in wild boars (Sus scrofa) in the Slovak Republic. Ann Agric Environ Med. 2007; 14(1): 71-73.

4. Roqueplo C, Blaga R, Jean-Lou M, Vallee I, Davoust B. Seroprevalence of Toxoplasma gondii in hunted wild boars (Sus scrofa) from southeastern France. Folia Parasitol (Praha). 2017; 64:003. https://doi.org/10.14411/ fp. 2017.003

5. European Food Safety Authority. Surveillance and monitoring of Toxoplasma in humans, food and animals, Scientific Opinion of the Panel on Biological Hazards. The EFSA Journal 2007; 583: 1-64. https:// doi.org/10.2903/j.efsa.2007.583

6. Winter M, Abate SD, Pasqualetti MI, Fariña FA, Ercole ME, Pardini L, et al. Toxoplasma gondii and Trichinella infections in wild boars (Sus scrofa) from Northeastern Patagonia, Argentina. Prev Vet Med. 2019; 168: 75-80. https://doi.org/10.1016/j.prevetmed.2019.04.014

7. FAO. FAO identifies top 10 foodborne parasites. Vet Rec. 2014; 175(3): 58. https://doi.org/10.1136/vr.g4607

8. Dubey JP. History of the discovery of the life cycle of Toxoplasma gondii. Int J Parasitol. 2009; 39(8): 877-882. https://doi.org/10.1016/j. ijpara.2009.01.005

9. Račka K, Bártová E, Budíková M, Vodrážka P. Survey of Toxoplasma gondii antibodies in meat juice of wild boar (Sus scrofa) in several districts of the Czech Republic. Ann Agric Environ Med. 2015; 22(2): 231-235. https://doi.org/10.5604/12321966.1152071

10. Olsen A, Berg R, Tagel M, Must K, Deksne G, Enemark HL, et al. Seroprevalence of Toxoplasma gondii in domestic pigs, sheep, cattle, wild boars, and moose in the Nordic-Baltic region: A systematic review and meta-analysis. Parasite Epidemiol Control. 2019; 5: e00100. https:// doi.org/10.1016/j.parepi.2019.e00100

11. Jones JL, Dubey JP. Foodborne toxoplasmosis. Clin Infect Dis. 2012; 55(6): 845-851. https://doi.org/10.1093/cid/cis508

12. Tenter AM, Heckeroth AR, Weiss LM. Toxoplasma gondii: from animals to humans. Int J Parasitol. 2000; 30(12-13): 1217-1258. https:// doi.org/10.1016/s0020-7519(00)00124-7

13. Rostami A, Keshavarz H, Shojaee S, Mohebali M, Meamar AR. Frequency of Toxoplasma gondii in HIV positive patients from west of Iran by ELISA and PCR. Iran J Parasitol. 2014; 9(4): 474-481.

14. Pereira-Chioccola VL, Vidal JE, Su C. Toxoplasma gondii infection and cerebral toxoplasmosis in HIV-infected patients. Future Microbiol 2009; 4(10): 1363-1379. https://doi.org/10.2217/fmb.09.89

15. Montoya JG, Liesenfeld O. Toxoplasmosis. Lancet. 2004; 363(9425): 1965-1976. https://doi.org/10.1016/S0140-6736(04)16412-X

16. Nourollahpour Shiadeh M, Rostami A, Pearce BD, Gholipourmalekabadi M, Newport DJ, Danesh M, Mehravar S, Seyyedtabaei SJ. The correlation between Toxoplasma gondii infection and prenatal depression in pregnant women. Eur J Clin Microbiol Infect Dis. 2016; 35(11): 1829 1835. https://doi.org/10.1007/s10096-016-2734-5

17. Nourollahpour Shiadeh M, Behboodi Moghadam Z, Adam I, Saber V, Bagheri M, Rostami A. Human infectious diseases and risk of preeclampsia: an updated review of the literature. Infection. 2017; 45(5): 589-600. https://doi.org/10.1007/s15010-017-1031-2

18. Rostami A, Riahi SM, Fakhri Y, Saber V, Hanifehpour H, Valizadeh S, Gholizadeh M, Pouya RH, Gamble HR. The global seroprevalence of Toxoplasma gondii among wild boars: A systematic review and meta-analysis. Vet Parasitol. 2017; 244: 12-20. https://doi.org/10.1016/j. vetpar.2017.07.013

19. Fallahi S, Rostami A, Birjandi M, Zebardast N, Kheirandish F, Spotin A. Parkinson's disease and Toxoplasma gondii infection: Sero-molecular assess the possible link among patients. Acta Trop. 2017; 173: 97-101. https://doi.org/10.1016/j.actatropica.2017.06.002

20. Rostami A, Seyyedtabaei SJ, Aghamolaie S, Behniafar H, Lasjerdi Z, Abdolrasouli A, Mehravar S, Alvarado-Esquivel C. Seroprevalence and risk factors associated with Toxoplasma gondii infection among rural communities in northern Iran. Rev Inst Med Trop Sao Paulo. 2016; 58 : 70. https://doi.org/10.1590/S1678-9946201658070
21. Shiadeh MN, Niyyati M, Fallahi S, Rostami A. Human parasitic protozoan infection to infertility: a systematic review. Parasitol Res. 2016; 115(2): 469-477. https://doi.org/10.1007/s00436-015-4827-y

22. Sutterland AL, Fond G, Kuin A, Koeter MW, Lutter R, van Gool T, Yolken R, Szoke A, Leboyer M, de Haan L. Beyond the association. Toxoplasma gondii in schizophrenia, bipolar disorder, and addiction: systematic review and meta-analysis. Acta Psychiatr Scand. 2015; 132(3): 161-179. https://doi.org/10.1111/acps.12423

23. Praca zbiorowa. Łowiectwo. Tom I. Wyd. Łowiec Polski, 2011. [in Polish]

24. Praca zbiorowa. Łowiectwo. Tradycje, prawo, zwierzyna. Wyd. SBM, 2015. [in Polish]

25. Touloudi A, Valiakos G, Athanasiou LV, Birtsas P, Giannakopoulos A, Papaspyropoulos K, et al. A serosurvey for selected pathogens in Greek European wild boar. Vet Rec Open.2015; 2(2): e000077. https:// doi.org/10.1136/vetreco-2014-000077

26. Statistical Yearbook of Forestry. Statistics Poland, 2018.

27. Pedersen K, Bauer NE, Rodgers S, Bazan LR, Mesenbrink BT, Gidlewski T. Antibodies to various zoonotic pathogens detected in feral swine (Sus scrofa) at abattoirs in Texas, USA. J Food Prot. 2017; 80(8): 1239-1242. https://doi.org/10.4315/0362-028X.JFP-17-016

28. Cleveland CA, DeNicola A, Dubey JP, Hill DE, Berghaus RD, Yabsley MJ. Survey for selected pathogens in wild pigs (Sus scrofa) from Guam, Marianna Islands, USA. Vet Microbiol. 2017; 205: 22-25. https://doi. org/10.1016/j.vetmic.2017.05.001

29. Malmsten A, Magnusson U, Ruiz-Fons F, González-Barrio D, Dalin AM. A serologic survey of pathogens in wild boar (Sus scrofa) in Sweden. J Wildl Dis. 2018; 54(2): 229-237. https://doi.org/10.7589/2017$05-120$

30. Sandfoss M, DePerno C, Patton S, Flowers J, Kennedy-Stoskopf S. Prevalence of antibody to Toxoplasma gondii and Trichinella spp. in feral pigs (Sus scrofa) of eastern North Carolina. J Wildl Dis. 2011; 47(2): 338-343. https://doi.org/10.7589/0090-3558-47.2.338

31. Slany M, Reslova N, Babak V, Lorencova A. Molecular characterization of Toxoplasma gondii in pork meat from different production systems in the Czech Republic. Int J Food Microbiol. 2016; 238: 252-255. https:// doi.org/10.1016/j.ijfoodmicro.2016.09.020

32. Gazzonis AL, Villa L, Riehn K, Hamedy A, Minazzi S, Olivieri E, et al. Occurrence of selected zoonotic food-borne parasites and first molecular identification of Alaria alata in wild boars (Sus scrofa) in Italy. Parasitol Res.2018; 117(7): 2207-2215. https://doi.org/10.1007/ s00436-018-5908-5

33. Herrero L, Gracia MJ, Pérez-Arquillué C, Lázaro R, Herrera M, Herrera A, et al. Toxoplasma gondii: Pig seroprevalence, associated risk factors and viability in fresh pork meat. Vet Parasitol. 2016; 224: 52-59. https:// doi.org/10.1016/j.vetpar.2016.05.010

34. Wiszniewska-Łaszczych A, Wysok B, Wojtacka J, Szteyn J, Michalski MM, Sołtysiuk M. High seroprevalence of Toxoplasma gondii antibodies in wild boars hunted in the Game Breeding Center in north-eastern Poland. Med. Weter. 2019; 75(12): 759-762. https://doi. org/10.21521/mw.6345

35. Jeong W, Yoon H, Kim YK, Moon OK, Kim DS, An DJ. Prevalence of antibodies to Toxoplasma gondii in South Korean wild boar (Sus scrofa coreanus). J Wildl Dis. 2014; 50(4): 902-905. https://doi. org/10.7589/2013-03-077

36. Bartoszek K, Orłowska B, Anusz K. Food-chain biosecurity elements preventing Toxoplasma gondii infection in humans and animals. Życie Weterynaryjne 2011; 86(9): 714-716. [in Polish]

37. Bártová E, Sedlák K, Literák I. Prevalence of Toxoplasma gondii and Neospora caninum antibodies in wild boars in the Czech Republic. Vet Parasitol. 2006; 142(1-2): 150-153. https://doi.org/10.1016/j. vetpar.2006.06.022

38. Jokelainen P, Velström K, Lassen B. Seroprevalence of Toxoplasma gondii in free-ranging wild boars hunted for human consumption in Estonia. Acta Vet Scand. 2015; 57: 42. https://doi.org/10.1186/s13028015-0133-z

39. Opsteegh M, Swart A, Fonville M, Dekkers L, van der Giessen J. Age-related Toxoplasma gondii seroprevalence in Dutch wild boar inconsistent with lifelong persistence of antibodies. PLoS One. 2011; 6(1): e16240. https://doi.org/10.1371/journal.pone.0016240

40. Calero-Bernal R, Gómez-Gordo L, Saugar JM, Frontera E, PérezMartín JE, Reina D, Serrano FJ, Fuentes I. Congenital toxoplasmosis in wild boar (Sus scrofa) and identification of the Toxoplasma gondii types involved. J Wildl Dis. 2013; 49(4): 1019-1023. https://doi. org/10.7589/2013-01-024

41. Basso W, Hartnack S, Pardini L, Maksimov P, Koudela B, Venturini $\mathrm{MC}$, et al. Assessment of diagnostic accuracy of a commercial ELISA for the detection of Toxoplasma gondii infection in pigs compared with 
IFAT, TgSAG1-ELISA and Western blot, using a Bayesian latent class approach. Int J Parasitol.2013; 43(7): 565-570. https://doi.org/10.1016/j. ijpara.2013.02.003

42. Matsumoto J, Kako Y, Morita Y, Kabeya H, Sakano C, Nagai A, et al. Seroprevalence of Toxoplasma gondii in wild boars (Sus scrofa leucomystax) and wild sika deer (Cervus nippon) in Gunma Prefecture, Japan. Parasitol Int. 2011; 60(3): 331-332. https://doi.org/10.1016/j. parint.2011.05.005

43. Hill DE, Dubey JP, Baroch JA, Swafford SR, Fournet VF, HawkinsCooper D, et al. Surveillance of feral swine for Trichinella spp. and Toxoplasma gondii in the USA and host-related factors associated with infection. Vet Parasitol.2014; 205(3-4):653-665. https://doi. org/10.1016/j.vetpar.2014.07.026

44. Fornazari F, Langoni H, da Silva RC, Guazzelli A, Ribeiro MG, Chiacchio SB. Toxoplasma gondii infection in wild boars (Sus scrofa) bred in Brazil. Vet Parasitol. 2009; 164(2-4): 333-334. https://doi. org/10.1016/j.vetpar.2009.05.005

45. Bai MJ, Zou Y, Elsheikha HM, Ma JG, Zheng WB, Zhao Q, et al. Toxoplasma gondii infection in farmed wild boars (Sus scrofa) in three cities of Northeast China. Foodborne Pathog Dis. 2017; 14(7): 379-385. https://doi.org/10.1089/fpd.2016.2260

46. Luo H, Li K, Shahzad M, Zhang H, Lan Y, Xiong X. Seroprevalence of Toxoplasma gondii infection in wild boars, wild rabbits, and wild chickens in Hubei Province, China. Korean J Parasitol. 2017; 55(1): 85-88. https://doi.org/10.3347/kjp.2017.55.1.85

47. Kang SW, Doan HT, Noh JH, Choe SE, Yoo MS, Kim YH, et al. Seroprevalence of Toxoplasma gondii and Trichinella spiralis infections in wild boars (Sus scrofa) in Korea. Parasitol Int. 2013; 62(6): 583-585. https://doi.org/10.1016/j.parint.2013.08.015

48. Gauss CB, Dubey JP, Vidal D, Ruiz F, Vicente J, Marco I et al. Seroprevalence of Toxoplasma gondii in wild pigs (Sus scrofa) from Spain. Vet Parasitol. 2005; 131(1-2): 151-156. https://doi.org/10.1016/j. vetpar.2005.04.023

49. Wallander C, Frössling J, Vågsholm I, Uggla A, Lundén A. Toxoplasma gondii seroprevalence in wild boars (Sus scrofa) in Sweden and evaluation of ELISA test performance. Epidemiol Infect. 2015; 143(9): 1913-1921. https://doi.org/10.1017/S0950268814002891

50. Calero-Bernal R, Pérez-Martín JE, Reina D, Serrano FJ, Frontera E, Fuentes I, et al. Detection of zoonotic protozoa Toxoplasma gondii and Sarcocystis suihominis in wild boars from Spain. Zoonoses Public Health. 2016; 63(5): 346-350. https://doi.org/10.1111/zph.12243

51. Richomme C, Aubert D, Gilot-Fromont E, Ajzenberg D, Mercier A, Ducrot C, et al. Genetic characterization of Toxoplasma gondii from wild boar (Sus scrofa) in France. Vet Parasitol. 2009; 164(2-4): 296-300. https://doi.org/10.1016/j.vetpar.2009.06.014
52. Jokelainen P, Näreaho A, Hälli O, Heinonen M, Sukura A. Farmed wild boars exposed to Toxoplasma gondii and Trichinella spp. Vet Parasitol. 2012; 187(1-2): 323-327. https://doi.org/10.1016/j.vetpar.2011.12.026

53. Laforet CK, Deksne G, Petersen HH, Jokelainen P, Johansen MV, Lassen B. Toxoplasma gondii seroprevalence in extensively farmed wild boars (Sus scrofa) in Denmark. Acta Vet Scand. 2019; 61(1): 4. https://doi. org/10.1186/s13028-019-0440-x

54. Paştiu AI, Györke A, Blaga R, Mircean V, Rosenthal BM, Cozma V. In Romania, exposure to Toxoplasma gondii occurs twice as often in swine raised for familial consumption as in hunted wild boar, but occurs rarely, if ever, among fattening pigs raised in confinement. Parasitol Res. 2013; 112(6): 2403-2407. https://doi.org/10.1007/s00436-013-3353-Z

55. Ranucci D, Veronesi F, Moretti A, Branciari R, Miraglia D, Manfredi MT, et al. Seroprevalence of Toxoplasma gondii in wild boars (Sus scrofa) from Central Italy. Parasite. 2013; 20: 48. https://doi.org/10.1051/ parasite/2013048

56. Deksne G, Kirjušina M. Seroprevalence of Toxoplasma gondii in domestic pigs (Sus scrofa domestica) and wild boars (Sus scrofa) in Latvia. J Parasitol. 2013; 99(1): 44-47. https://doi.org/10.1645/GE-3187.1

57. Sroka J, Zwoliński J, Dutkiewicz J. Seroprevalence of Toxoplasma gondii in farm and wild animals from the area of Lublin province. Bull Vet Inst Pulawy 2007; 51: 535-540.

58. Witkowski L, Czopowicz M, Nagy DA, Potarniche AV, Aoanei MA, Imomov N. et al. Seroprevalence of Toxoplasma gondii in wild boars, red deer and roe deer in Poland. Parasite. 2015; 22: 17. https://doi. org/10.1051/parasite/2015017

59. Kornacka A, Cybulska A, Popiołek M, Kuśmierek N, Moskwa B. Survey of Toxoplasma gondii and Neospora caninum in raccoons (Procyon lotor) from the Czech Republic, Germany and Poland. Vet Parasitol. 2018; 262: 47-50. https://doi.org/10.1016/j.vetpar.2018.09.006

60. Majewska AC, Werner A, Cabaj W, Moskwa B. The first report of Toxoplasma gondii antibodies in free-living European bison (Bison bonasus Linnaeus). Folia Parasitol (Praha). 2014; 61(1): 18-20. https:// doi.org/10.14411/fp.2014.012

61. Dubey JP. Toxoplasmosis in pigs-the last 20 years. Vet Parasitol. 2009; 164(2-4): 89-103. https://doi.org/10.1016/j.vetpar.2009.05.018

62. Statistical Yearbook of the Republic of Poland. Statistics Poland, 2019.

63. Lopes AP, Sargo R, Rodrigues M, Cardoso L. High seroprevalence of antibodies to Toxoplasma gondii in wild animals from Portugal. Parasitol Res. 2011; 108(5): 1163-1169. https://doi.org/10.1007/s00436010-2158-6

64. Kijlstra A, Meerburg B, Cornelissen J, De Craeye S, Vereijken P, Jongert E. The role of rodents and shrews in the transmission of Toxoplasma gondii to pigs. Vet Parasitol. 2008; 156(3-4): 183-190. https://doi. org/10.1016/j.vetpar.2008.05.030 